Summer 1999

\title{
Hell Hath No Fury Like a Fan Scorned: State Regulation of Sports Agents
}

Phillip J. Closius

University of Baltimore School of Law, pclosius@ubalt.edu

Follow this and additional works at: http://scholarworks.law.ubalt.edu/all_fac

Part of the Entertainment, Arts, and Sports Law Commons

\section{Recommended Citation}

Hell Hath No Fury Like a Fan Scorned: State Regulation of Sports Agents, 30 Toledo L.Rev. 511 (1999)

This Article is brought to you for free and open access by the Faculty Scholarship at ScholarWorks@University of Baltimore School of Law. It has been accepted for inclusion in All Faculty Scholarship by an authorized administrator of ScholarWorks@University of Baltimore School of Law. For more information, please contact snolan@ubalt.edu. 


\section{The University of Toledo}

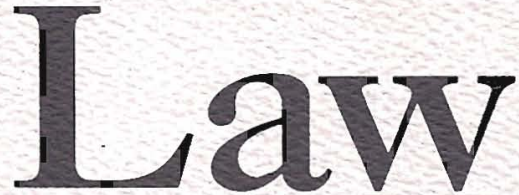

VOLUME 30
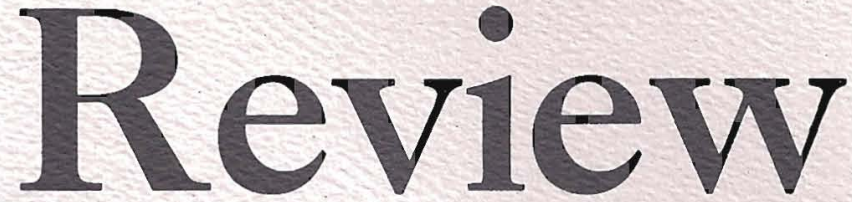

NUMBER 4

SUMMER 1999

\section{THIRTIETH ANNIVERSARY ISSUE}

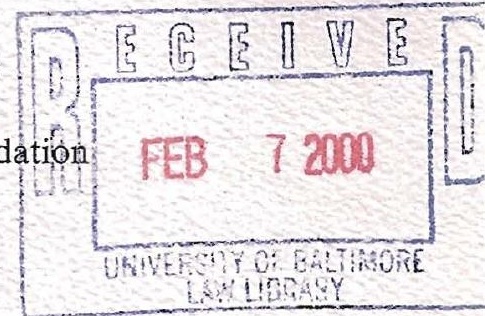

An Irreverent and Idiosyncratic Review of the Historical Foundation FEB 72000 of the University of Toledo Law Review

Gerald P. Moran

\section{ARTICLES}

Hell Hath No Fury like a Fan Scorned: State Regulation of Sports Agents Phillip J. Closius

Design Principles for Universal Legal Citations Bruce M. Kennedy

Understanding the Multiple Dimensions of Regulatory Takings: A Matrix Robert J. Hopperton

A Model Statute to Provide Foreign-Language Interpreters in the Ohio Courts Alice J. Baker

\section{NOTES}

No-Drop Policies: Effective Legislation or Protectionist Attitude?

Cathleen A. Booth

Cleansing the System: A Fresh Approach to Liability for the Negligent or Fraudulent Transmission of Sexually Transmitted Diseases

David J. Mack

Discrimination Perfected to a Science: The Evolution of the Supreme Court's War on Drugs Katrina Quicker

INDEX TO VOLUME 30 


\title{
ARTICLES
}

\section{HELL HATH NO FURY LIKE A FAN SCORNED. STATE REGULATION OF SPORTS AGENTS}

\author{
Phillip J. Closius
}

\section{INTRODUCTION}

TNTERCOLLEGIATE athletıcs has evolved from local, student organized games in the early twentieth century into a national, multi-billion dollar industry in the twenty-first century ${ }^{1}$ This development has occurred in a context of dynamic tension between amateurism and student ideals on the one hand and professionalism, competitiveness, and financial gain on the other. The National Collegiate Athletic Association (NCAA), the major regulatory association for such intercollegiate competitions for most of this period, has publicly nurtured the ideal of the "amateur student-athlete" and has maintained stringent and detailed rules and regulations prohibitıng the collegiate athlete from receiving any benefit of any kind based on athletıc talent while he or she retains amateur eligibility. ${ }^{2}$ In contrast to this NCAA sponsored image, reports of payments to and preferential treatment for collegiate athletes have been equally prevalent from the beginning of the twentieth century ${ }^{3}$ The uneasy co-exıstence between the public perception of "amateur student-athlete" and the private reality of payments and preferences grew more tense as Division I athletıcs, partıcularly football and basketball, began to attract national media attentıon and to generate millions of dollars in income. ${ }^{4}$ As the rewards for winning increased,

* Dean and Professor of Law, The University of Toledo College of Law. J.D., Columbia University School of Law (1975); B.A., University of Notre Dame (1972). The author gratefully acknowledges a sabbatical leave and a partial Universtty of Toledo College of Law Summer Research Grant, which provided financial support for the research and writıng of this article. LeAnne Gilbert provided invaluable research assistance. (1997).

1. See Jan Stıglitz, A Modest Proposal: Agent Deregulation, 7 MARQ. SPORTS L.J. 361, 368

2. See NCAA CONST. art. 1, § 1.3.I in NATIONAL COLLEGIATE ATHLETIC ASSOCIATION MANUAL 1998-1999, at 1 [hereinafter NCAA MANUAL]. See also Jan Stıglitz, NCAA Based Agent Regulation: Who Are We Protecting? 67 N.D. L. REV 215, 217 (1991).

3. Some commentators have noted special benefits and payments to athletes appearing in ancient Greece. See W Jack Grosse \& Enc Warren, The Regulation, Control, and Protection of Athlete Agents, 19 N. KY. L. REV 49, 49 (1991). Preferentıal admission standards, professors who give athletes unearned high grades, summer jobs with no work involved, cash payments, free meals and clothing are only some of the "illegal" benefits widely portrayed in the media as being given to collegiate athletes. See Mike McGraw et al., Money Games: Inside the NCAA, KAN. CiTY STAR, Oct. 5, 1997, at Al (six-part series).

4. See Ricardo J. Bascuas, Note: Cheaters, Not Criminals: Antitrust Invalidation of Statutes Outlawing Sports Agent Recruitment of Student Athletes, 105 YALE L.J. 1603, 1606-07 (1996). 
the pressure to gain a recruitıng edge or keep talented athletes academıcally eligible encouraged universities to ignore the "principles of amateurism." At the same time, the NCAA reinforced its commitment to the model of the "student-athlete" and strengthened the severity of sanctions that it may impose on an offending institution, including, but not limited to, forfeiture of games played by compromised athletes, return of revenue generated by "tainted" games, and limitations on the institution's ability to recruit future athletes. ${ }^{6}$

Prior to the 1970 s, the battle for amateurism was waged mainly between the NCAA and a university's "institutional representatıves"-coaches and boosters or alumn $1 .{ }^{7}$ In the late 1960s, the occupation of "sports agent" emerged and individuals of all kınds suddenly appeared on campus offering a variety of inducements to athletes in exchange for the execution of a representation agreement. ${ }^{8}$ The introduction of the agent disrupted the uneasy equilibrium which had been maintained for decades between the public image and the private reality of Division I athletıcs. The "principles of amateurısm" were now being flaunted by agents - individuals not under the "institutional control" of any university NCAA sanctions were imposed on universities when no institutional personnel had been involved in the violation of NCAA rules. The century old balance between the illusion of the "student-athlete" and the reality of payments and preferences, which had allowed intercollegiate football and basketball to flourısh, was being threatened by the "uncontrolled" activities of the agents."

The business practices of Norby Walters and Lloyd Bloom in the early 1980 s brought the new reality of intercollegiate sports to a head. Walters and Bloom were talent agents in the recording industry who decided to represent athletes. In 1986, they signed a large number of college football players, most of whom were early draft picks, to representation contracts. ${ }^{10}$ The immediate success of the duo engendered rumors of extravagant payments to players and the signing of post-dated contracts before the expiration of an athlete's eligibility ${ }^{11}$ Allegations of Walters' and Bloom's ties to organized crime and their reported physical threats to the lives and well-beıng of rival agents and dissatısfied players brought a new level of crimınality to Division I athletıcs. ${ }^{12}$ In the course of numerous lawsuits regarding these two

5. NCAA MANUAL, supra note 2 , art. 12 (Operatıng Bylaws).

6. See id. $\S 19.6$, at 346-50 (Operating Bylaws). The NCAA can now also impose the so-called "death penalty" (ineligibility to field a team) for multıple violators. These varied sanctions cost the institution financially and embarrass it nationally.

7. See NCAA MANUAL, supra note 2, §6.42 (Operatıng Bylaws).

8. See Lionel S. Sobel, The Regulation of Player Agents and Lawyers, in A LAW OF PROFESSIONAL AND AMATEUR SPORTS $§ 1.01$ at I3-I5 (Gary A. Uberstıne ed., 1988); Philip N. Fluhr, Jr., The Regulation of Sports Agents and the Quest for Uniformity, 6 SPORTS LAW. J. 1, 2 (1999).

9. See Jeffrey P Crandall, Note, The Agent-Athlete Relationship in Professional and Amateur Sports: The Inherent Potential for Abuse and the Need for Regulation, 30 BUFF L. REV 815, 824-25 (1981). See also David L. Dunn, Note, Regulation of Sports Agents: Since at First It Hasn't Succeeded, Try Federal Legislation, 39 HAST. L.J. 1031, 1037-38 (1988) (discussing reported incidents of agent misconduct in the early 1980s).

10. See Grosse \& Warren, supra note 3, at 65 .

11. See Dunn, supra note 9, at 1032.

12. See Bascuas, supra note 4, at 1611-12. See also Grosse \& Warren, supra note 3, at 66 (discussing the prosecution of Walters and Bloom for violations of RICO). 
agents, the extent of intercollegiate corruption was publicly revealed. In a federal criminal prosecution of the duo, approximately fifty football players were subpoenaed by the government to testify against Bloom and Walters. ${ }^{13}$ All of the players had received money and other valuable consideration in exchange for signing post-dated representation contracts before the beginning of their senior season. The athletes were from every comer of the country and every type of college and university, including traditionally "clean" programs. ${ }^{14}$ These activities finally culminated in the conviction and sentencing of Bloom and Walters on five counts of racketeerıng and mail fraud. ${ }^{\text {s }}$

The breadth of the corruption and the easy availability of the athletes to the agents shocked the country In response to the public outcry following these revelations, states began to pass legislation criminalizıng conduct by sports agents that jeopardized a student athlete's eligibility under NCAA rules. ${ }^{16}$ This legislatıve trend is not directed at helping the student-athlete, especially with graduation rates below $40 \%$ at many programs and athletes who do procure degrees frequently receive them in meaningless majors. ${ }^{17}$ By restrictıng an athlete's ability to discover information about his/her market value, these statutes have been perceived as part of the monopolistic structure that depresses player compensation and rights in an industry which grosses billions of dollars from player's efforts. ${ }^{18}$ The states are therefore using their legislative and judicial processes to promote the narrowest provincial goals possible - the competitıve advantage of intercollegıate football and basketball teams withın the state and the granting of preferences and payments to athletes only by institutional representatives.

These statutes have the effect of giving NCAA regulations the full force of law This in essence crimınalizes rules made by a private association to benefit its own members. Although the use of state law to further the goals of a private entity would predictably have deleterious effects, the obvious disadvantages are considerably increased when the private entity is the NCAA and the arena is intercollegiate Division I athletıcs. ${ }^{19}$ NCAA rules are incredibly detailed and, on their face, prohibit the conferral of any student "benefit" because of his or her athletic ability ${ }^{20}$ Many experts have trouble understanding the tangled maze of NCAA bylaws and interpretations. ${ }^{21}$ Inadvertent violations occur with some frequency To avold this tangled web, many state statutes are triggered by any contact, even mere speech, between the agent and a student-athlete. ${ }^{22}$ In addition, the culture of intercollegiate

13. See United States v. Walters, 913 F.2d 388, 390 (7th Cir. 1990).

14. See Grosse \& Warren, supra note 3, at 66.

15. See Walters, 913 F.2d at 390.

16. See Grosse \& Warren, supra note 3, at 56-64. See also Dunn, supra note 9, at 1063 (noting only Califomia, Oklahoma and Texas had statutes in July, 1988).

17 See Stiglitz, supra note 2, at 222; Fluhr, supra note 8, at 25. See also McGraw, supra note 3, Failing the Grade (pt. 6) (listing graduation rates).

18. See Fluhr, supra note 8, at 22-23. See also Bascuas, supra note 4, at 1628-29 (citing Judge Easterbrook as stating prosecutors use criminal laws and contract-restricting statutes "to suppress the competitive process").

19. See Fluhr, supra note 8, at 24.

20. See NCAA MANUAL, supra note $2, \S 12.1 .1 .1 .4$ (Operating Bylaws).

21. See Grosse \& Warren, supra note 3, at 51-52.

22. See Cal. BuS. \& Prof. Code ANN. $\$ 18897.63$ (West Supp. 1999); Fla. Stat. ANN. 
athletics is to disregard NCAA rules to a certain extent, either because strict compliance is impossible or because gross violations provide a competitive recruiting advantage. In this atmosphere, the state's law is likely to be ignored by agents and athletes for similar reasons. ${ }^{23}$ This reality enforces the belief rampant in collegiate sports that violatıng NCAA rules is not a problem, but gettıng caught is. The only people likely to be prosecuted in such an environment are those whose violations are publicized by a different entity such as the media or an ancillary legal proceeding. In these instances, the violation catches the attention of state officials. ${ }^{24}$

No existıng or proposed state statute regulates or crimınalizes the activities of college or university coaches, booster, or alumn. This omission would appear to be glaringly inconsistent with the state s professed goals of preserving student eligibility and preventıng penalties or disqualifications from affectıng in-state universitıes and colleges. Payments and other benefits given by coaches or institutional representatives are as clear a violation of NCAA rules as inducements given by agents to players. ${ }^{25}$ If violations by coaches and boosters are more likely to result in NCAA sanctions, the omission of such groups from the sweep of state legislation only confirms that NCAA rules are widely ignored, the statues are woefully underınclusive regarding their purposes, and the states are incredibly provincial in the creation and enforcement of these statutes.

This artıcle first describes the exıstıng system of state statutes regulatıng sports agents, including the proposed Model Uniform Athlete Agents Act. The article then examınes the validity of these statutes in the context of jurisdictional limitations and dormant Commerce Clause principles. Lastly federal regulation and the rules of professional sports unions are considered as alternatives to state legislative activity

\section{STAte Statutes}

State regulation of the sports agent business began in the early 1980s in California ${ }^{26}$ The few statutes in existence prior to the Norby Walters revelations essentially followed the California model and analogized sports agencies to employment agencies. ${ }^{27}$ These statutes typically required registration with a state agency and the disclosure of certain information to the state, usually a standard form representation agreement and fee disclosure, if an individual desired to do business within the jurisdiction. ${ }^{28}$ In the 1990 s, a new wave of more detailed legislation has occurred. To date, twenty-seven states have enacted statutes which regulate sports

$\S 468.453$ (West Supp. 1999); IOWA CODE ANN. § 9A.8(3) (West 1995); MD. CODE ANN., Bus. REG. $\S 4-402$ (1998); MiCH. COMP. LAWS ANN. $\$ 750.41$ le(1) (West 1998); TEXAS Bus. \& COM. CODE ANN. $\S 8871(6)(\mathrm{b})(3)$ (Supp. 1999).

23. See Dunn, supra note 9, at 1051, Fluhr, supra note 8 , at 23.

24. See Bascuas, supra note 4 , at 1610-14.

25. See NCAA MANUAL, supra note $2, \S 12.1 .1 .1 .4$ (Operatıng Bylaws).

26. See CAL. LAB. CODE $\$ 1500$ (West 1972). This statute was replaced by CAL. BuS. \& PROF CODE $§ 18895$ (West Supp. 1999).

27 See generally Zinn v. Parnsh, 461 F Supp. 11 (N.D. Ill. 1977), rev d, 644 F.2d 360 (7th Cir. $1981)$.

28. See CAl. LaB. CODE $\S \S 1510,1511$ (West 1972). 
agent activity ${ }^{29}$ Of the twenty-three states without such statutes, sixteen have never enacted a sports agent statute and have no bills pending ${ }^{30} \mathrm{six}$ have bills pending ${ }^{31}$ and one has recently repealed its statute with no bills pending to replace it. ${ }^{32}$ Although consistent in their intent to "protect" in-state collegiate athletes from the influence of sports agents, the statutes vary regarding their jurısdictional reach, registration requirements, substantive prohibitions, and imposed sanctions.

The jurisdictional scope of these statutes is centered in the definition of "studentathlete." The majority of the states define a student-athlete as a resident of the state or a student at an educational institution located within the state who participates or is eligible to partıcipate in athletıcs. ${ }^{33}$ A more aggressıve expansion of these regulations is found in a second type of statute. These statutes contain the same definition of student-athlete delineated in the first group, but additionally include anyone who has indicated an intent, usually in writıng, to participate in athletics at an in-state institution. ${ }^{34}$ This modern trend extends the requirements of the statute to include contacts with prospective students who may live in another state and have only been in the state a few tımes. Although every other state defines "athletics" broadly, Texas specifically limits its statute to include only students participatıng in football and basketball. ${ }^{35}$

29. See AlA. CODE $\S \S 8-26-1$ to -41 (Supp. 1998); ARK. CODE ANN. \$§ 17-16-101 to -203 (1992); CAL. BuS. \& PROF CODE $\$ \S 18897.1-.97$ (West Supp. 1999); Colo. REV STAT. ANN. $\S \S 23-$ 16-101 to -108 (West Supp. 1999); CONN. GEN. STAT. ANN. $\$ \S 20-553$ to 558 (West Supp. 1999); FLA. STAT. ANN. \$\$ 468.451-4571 (West Supp. 1999); GA. CODE ANN. \$§ 43-4A-1 to -19 (1994); IND. CODE ANN. $\S \S 35-46-4-1$ to -4 (West 1998); IOWA CODE ANN. \$§ 9A.1-.12 (West 1995); KAN. STAT. ANN. §§ 44-1501 to -1515 (1999); KY. REv. STAT. ANN. §§ 164.680-.689 (Banks-Baldwin Supp. 1998); LA. REV. STAT. ANN. \$§ 4:421-430 (1987 \& Supp. 1999); MD. CODE ANN., BuS. REG. $\$ \$ 4-401$ to -426 (Supp. 1999); MICH. COMP LAWS ANN. $\$ 750.411$ e (West 1991); MINN. STAT. ANN. $\S 325 E .33$ (West 1995); Miss. CODE ANN. $\$$ 73-41-1 to -23 (1995 \& Supp. 1998); MO. ANN. STAT. $\S \S 436.200-.209$ (West Supp. 1999); NEV. REV. STAT. ANN. $\$ \S 398.005-255$ (West 1996); N.C. GEN. STAT. $\$ \S 78 C-71$ to -81 (1990); N.D. CENT. CODE $\S \S 9-15-01$ to -05 (Supp. 1997); OHIO REV CODE ANN. $\S \S 4771.01-99$ (Banks-Baldwin 1999); OKLA. STAT. ANN. tt. 70, \$§ 821.61-.71 (West Supp. 1999); 5 PA. CONS. STAT. $\$ \S 3301-12$ (Supp. 1999); S.C. CODE ANN. $\S \S 59-102-10$ to 50 (Law. Coop. 1998); TENN. CODE ANN. §§ 49-7-2111 to -2121 (1996 \& Supp. 1998); TEX. Bus. \& COM. CODE ANN. § 8871 (West Supp. 1999); WASH. REV CODE ANN. $\$ \$ 18.175 .010-080$ (West Supp. 1999).

30. Alaska, Delaware, D.C., Hawaii, Idaho, Illinoıs, Maıne, Massachusetts, New Mexıco, New Hampshıre, Oregon, South Dakota, Utah, Vermont, Wisconsın and Wyoming have netther a statute nor a bill under consideration.

31. Nebraska, West Virgınıa, Arızona, Rhode Island, New York, and New Jersey have bills pending.

32. Virginta has recently repealed its statute and has no new bill under consideration.

33. See Kan. STAT. ANN. \$ 44-1502 (1998); MICH. COMP. LAWS. $\$ 750.411 \mathrm{e}$ (1998); N.D. CENT. CODE $\S \S 9-15-01$ to -02 (1998); WASH. REV CODE ANN. $\S \S 18.175 .030-070$ (West Supp 1998).

34. See Ala. CODE $\S \S 8-26-24$ to -41 (1998); CAL. BUS. \& PROF. CODE $\S \S 18895.2-.93$ (West Supp. 1998); Colo. Rev Stat. ANN. §§ 23-16-102 to -105 (West Supp. 1998); Fla. STat. ANN. $\S 468.452$ (West Supp. 1998); GA. CODE ANN. $\$ \$ 43-4 A-2$ to -16 (West Supp. 1998); IND. CODE ANN. $\S$ 4-5.1 (West Supp. 1998); lowa CODE ANN. $\S 91.8(1)$ (West Supp. 1998); MinN. Stat. ANN. $\S 325$ E.33 (West Supp. 1998); MISS. CODE ANN. \$§ 71-41-01 to -99 (1998); OKLA. STAT. ANN. tit. 821, $\$ 61$ (West Supp. 1998); PA. CoNS. STAT. ANN. $\$ 7107$ (West Supp. 1998); TENN. CODE ANN. $\S \S 49-7-2111$ to -2113 (1998).

35. See TeXAS BuS. \& COM. CODE ANN. $\$ 8871(C)$ (West Supp. 1998). Despite broader applicability, the other state regulations are really only concerned with football and men's basketball. See Stiglitz, supra note 2, at 216. 
Registration requirements reveal a more disparate pattern of regulation. A number of states do not require registration with the state or a posting of a surety bond prior to the contacting of or contracting with a student-athlete. ${ }^{36}$ Other states require state registration but do not mandate the postıng of a surety bond. ${ }^{37}$ Finally, a third group requires central registration and the posting of a surety bond, with the required bond amounts ranging from $\$ 10,000$ to $\$ 100,000 .{ }^{38}$ The majority of the states that require registration specify that the information be filed with the Secretary of State. ${ }^{39}$ The other states delineate a different state official to be in charge of registration, most typically a Commissioner of Consumer Protection or a special Agent Regulatory Commission. ${ }^{40}$ A recent trend is to test prospective agents on various sports law topics in addition to requiring an application, background check, and fee. ${ }^{41}$ Many states exempt members of the state's bar from the registration requirements. ${ }^{42}$

The substantive provisions of the statutes usually center on contact with the student-athlete and/or contractıng with the student-athlete. A number of states do not regulate contact at all, but merely focus on the event of contract execution. ${ }^{43}$ For those that do regulate contact, a small number of states impose an outright ban on contact between an agent and a student-athlete. ${ }^{44}$ The others mandate that no contact

36. See IND. CODE ANN. § 4-5.1 (West Supp. 1998); MiCH. COMP LAWS. $\$ 750.41$ le (1998); MINN. STAT. ANN. § 325E.33 (West Supp. 1998); NEV. REV. STAT. ANN. \$§ 398.015-398.065 (Michie 1998); N.D. CENT. CODE §§ 9-15-01 to -02 (1998); OHIO REV. CODE ANN. $\S \S 4771.01-4771.99$ (Banks-Baldwin 1998).

37 See CONN. GEN. STAT. ANN. §§ 20-555 to -558 (West Supp. 1998); LA. REV. STAT. ANN. § 4421 (West Supp. 1998); MO. ANN. STAT. $\$ 436.200$ (West Supp. 1998); OKLA. STAT. ANN. tit. 821, $\S 61$ (West Supp. 1998); S.C. CODE ANN. $\$$ 59-102 (Law Co-op. 1998); WASH. REV. CODE ANN. $\S \S 18.175 .030-18.175 .070$ (West Supp. 1998).

38. See ALA. CODE $\S \S 8-26-24$ to -41 (1998); ARK. CODE ANN. $\$ 17-16-01$ (Michie 1998); CAL. BuS. \& PROF CODE $\S \S 18895.2-18897.93$ (West Supp. 1998); Colo. REV. STAT. ANN. $\S \S 23-16-102$ to -105 (West Supp. 1998); FLA. STAT. ANN. $\$ 468.453$ (West Supp. 1998); GA. CODE ANN. §§ 43-4A2 to -16 (West Supp. 1998); IOWA CODE ANN. § 91.8(1) (West Supp. 1998); KAN. STAT. ANN. § 441502 (1998); KY. REV. STAT. ANN. $\$ \S 518.010-518.080$ (Banks-Baldwın 1998); MD. CODE ANN. BUS. OCC. \& PROF § 4-402 (1998); MISS. CODE ANN. \$\$ 71-41-01 to -99 (1998); N.C. GEN. STAT. \$§ 78C 71 to 78 (1998); PA. CONS. STAT. ANN, 67107 (West Supp. 1998); TENN. CODE ANN. \& \& s 49-7-2! ! ! to -2113 (1998); TEXAS BuS. \& COM. CODE ANN. \$ 8871 (West Supp. 1998).

39. See ARK. CODE ANN. \& 17-16-01 (Michre 1998); CAL. BUS. \& PROF. CODE $\S \S 18895.2-18897.93$ (West Supp. 1998); COLO. REV. STAT. ANN. $\S \S 23-16-102$ to -105 (West Supp. 1998); IOWA CODE ANN. § 91.8(1) (West Supp. 1998); KAN. STAT. ANN. § 44-1502 (1998); KY. REV STAT. ANN. $\S \S 518.010-518.080$ (Banks-Baldwin 1998); LA. REV STAT. ANN. $\$ 4-421$ (West Supp. 1998); MD. CODE ANN. BuS. OCC. \& PROF. § 4-402 (1998); MISS. CODE ANN. §§ 71-41-01 to -99 (1998); Mo. ANN. STAT. $\S 436.200$ (West Supp. 1998); N.C. GeN. STAT. $\S 78 \mathrm{C} 71$ to 78 (1998); OKLA. STAT. ANN. tit. 821, §61 (West Supp. 1998); TENN. CODE ANN. \$§ 49-7-2111 to -2113 (1998); TEX. BUS. \& COM. CODE ANN. § 8871 (West Supp. 1998).

40. See ALA. CODE $\$ \S 8-26-24$ to -41 (1998); CONN. GEN. STAT. ANN. $\S \S 20-555$ to -558 (West Supp. 1998); FLA. STAT. ANN. $\S 468.453$ (West Supp. 1998); GA. CODE ANN. §§ 43-4A-2 to -16 (West Supp. 1998); PA. CONS. STAT. ANN. $\$ 7107$ (West Supp. 1998); S.C. CODE ANN. § 59-102 (Law Coop. 1998); WASH. REV CODE ANN. $\$ \S 18.175 .030-18.175 .070$ (West Supp 1998).

41. See Fla. Stat. ANN. $\$ 468.453$ (West Supp. 1998).

42. See Ky. ReV Stat. ANN. § 518.010(3)(b); LA. REV Stat. ANN. § 40422(A); TEX. Bus. \& COM. CODE ANN. § 49-7-2112(5) (1998).

43. See Mich. COMP. LAwS. $\$ 750.411$ e (1998); TENN. CODE ANN. $\$ \S 49-7-2111$ to -2113 (1998).

44. See CAL. BuS. \& PROF CODE $\S \S 18895.2-18897.93$ (West Supp. 1998); MD. CODE ANN. 
occur until the registration process has been completed and approved. ${ }^{45}$ An exception usually exists for student initiated contact, with the agent required to begin the registration process a set number of days from the contact. ${ }^{46}$ The statute may also require the agent to notify the educational institution before contacting the studentathlete. ${ }^{47}$ These statutes do not provide guidance for agents if the institution tells an agent that he or she does not have permission to contact the athlete. Some statutes require, and a number of educational institutions host on their own, an official agent interview panel. ${ }^{48}$ Any contact which violates NCAA rules violates the statute.

The statutes usually mandate that a representation contract contain certain specified clauses. A boldface warning to the athlete that execution of the contract will result in his or her loss of eligibility is the most commonly imposed term. ${ }^{49} \mathrm{~A}$ few states require notice to the educational institution before any representation contract is executed, ${ }^{\text {so }}$ but most states require a copy of the contract to be filed with the educational institution within some designated period after execution, typically seventy-two hours or before the athlete's next scheduled game or event, whichever is sooner. ${ }^{\mathrm{SI}}$ Such statutes stipulate that the student-athlete may rescind the contract within a specified period of the date of execution. ${ }^{52} \mathrm{~A}$ few states include an outright ban on any representation contract between an agent and a student-athlete with remaining eligibility ${ }^{53}$ Any contract or contractual inducement that violates NCAA rules violates the statute..$^{54}$

The existing statutes impose harsh penalties for violations. A representation contract that does not comply with statutory requirements is void and cannot be enforced..$^{55}$ A violation of the statute is a misdemeanor ${ }^{56}$ or a felony, ${ }^{57}$ with

BuS. OCC. \& PROF. $\$ 4-402$ (1998); TEX. BuS. \& COM. CODE ANN. $\$ 8871$ (West Supp. 1998).

45. See Fla. STAT. ANN. $\$ 468.454$ (West Supp. 1998); GA. CODE ANN. $\S \S 43-4 A-2$ to -16 (West Supp. 1998).

46. See Cal. Bus. \& Prof Code $§ \S 18895.2-18897.93$ (West Supp. 1998); GA. CodE ANN. $\S \S 43-4 A-2$ to -16 (West Supp. 1998); TEX. BUS. \& COM. CODE ANN. $\S 8871$ (West Supp. 1998).

47. Cal. BuS. \& PROF CODE $\S \S 18895.2-18897.93$ (West Supp. 1998); Fla. STAT. ANN. $\S 468.454$ (West Supp. 1998); TENN. CODE ANN. \$§ 49-7-2111 to -21 13 (1998); TEX. Bus. \& COM. CODE ANN. $\$ 8871$ (West Supp. 1998).

48. See CAL. Bus. \& PROF CODE § 18897.63(e); TEX. BUS. \& COM. CODE ANN. § 8871 (West Supp. 1998); S.B. $6719 \S 424(6)(2)$, 221 st Leg. (N.Y 1997); S.B. 2642 § 5-73-6, 1997-98 Leg. Sess. (R.I. 1997); H.B. 825 § 4771.16(E), 122nd General Assembly (Oh1o 1997-98).

49. See KY. REV. STAT. ANN. § 518.015(3); OHIO REV. CODE ANN. § 4771.01(3); TENN. CODE ANN. § 49-7-2113(2).

50. See GA. CoDE ANN. §§ 43-4A-2 to -16 (West Supp. 1998).

51. See CAL. BUS. \& PROF CODE $\S \S 18895.2-18897.93$ (West Supp. 1998); Fla. STAT. ANN. $\S 468.454$ (West Supp. 1998); TENN. CODE ANN. §§ 49-7-2111 to -2113 (1998).

52. See Cal. BUS. \& PROF CODE $\S \S 18895.2-18897.93$ (West Supp. 1998); Fla. STat. ANN. $\S 468.454$ (West Supp. 1998); TENN. CODE ANN. \$§ 49-7-2111 to -2113 (1998).

53. See MD. CODE ANN. BUS. OCC. \& PROF. § 4-402 (1998); Mich. COMP LAWs. § 750.411e (1998).

54. See ALA. CODE § 8-26-14(g) (1998); KY. REV. STAT. ANN. § 518.050(5) (Banks-Baldwin 1998); L.B. $766 \S 7(5), 95$ th Leg., 1st Sess. (Neb. 1997) (adjourned durıng the 1998 Regular Session without being carried over).

55. See ARK. CODE ANN. § 17-16-01 (Michie 1998); ColO. REV STAT. ANN. §§ 23-16-102 to -105 (West Supp. 1998); GA. CODE ANN. $\$ \S 43-4 A-2$ to -16 (West Supp. 1998); IoWA CODE ANN. $\S 91.8(1)$ (West Supp. 1998); KAN. STAT. ANN. § 44-1502 (1998); MINN. STAT. ANN. § 325E.33 (West Supp. 1998); NEV. REV. STAT. ANN. §§ 398.015-398.065 (Michıe 1998); N.C. GEN. STAT. §§ 78C 71 
appropriate sentences indicated. In addition to incarceration, a fine of varying amounts can be imposed on the agent, including formulations where the fine is a multiple of any benefits conferred on the athlete in violation of NCAA rules. ${ }^{58}$ In the modern trend of aggressive statutes, an educational institution is allowed to sue the agent for any damage that the institution has suffered, including loss of revenue from NCAA-mandated forfeitures or sanctions. ${ }^{59}$ Some jurisdictions allow the institution to recover punitive damages. ${ }^{60}$ This panoply of sanctions can expose a noncomplyıng agent to sıgnificant civil and crimınal liability Although defined in terms of the student-athlete, no current state statute punishes an educational institution, its coaches or boosters or alumn for violating NCAA rules; only a few subject the student athlete to liability ${ }^{61}$ The burdens of compliance and all cıvil and crımınal liability are almost solely on the sports agent. ${ }^{62}$

Although legislative history varies throughout the states, the typical stated purpose of the legislation is "to register athlete agents and to regulate their practices for the purposes of avoiding the negative impacts that may result from improper activity or inadequate performance by athlete agents." listed as: (1) student ineligibility resultıng in a loss of an athletıc grant-ın-and and the athlete s withdrawal from the college or university prior to completion of his or her education; (2) penalties, forfettures, or disqualifications of colleges and universities which hinders their participation in intercollegiate athletics; (3) harmful consequences for professional sports; and (4) general detrimental effect on the people of

to -78 (1998); OHO REV. CODE ANN. $\$ \S 4771.01-4771.99$ (Banks-Baldwın 1998); TEX. BuS. \& COM. CODE ANN. $§ 8871$ (West Supp. 1998).

56. See CAL. Bus. \& PROF CODE ANN. $\S \S 18895.2-.93$ (West Supp. 1998); CONN. Gen. STAT. ANN. $\S \S 20-555$ to 558 (West Supp. 1998); lowa CODE ANN. $§ 91.8(1)$ (West Supp. 1998); MICH. COMP. LAWS $\S 750.411$ e (1998); LA. Rev STAT. ANN. $\$ 4-421$ (West Supp. 1998); MD. CoDE ANN. BuS. OCC. \& Prof $\$ 4-402$ (1998); Mo. ANN. STAT. $\$ 436.200$ (West Supp. 1998); N.D. CENT. CODE $\S \S 9-15-01$ to -02 (1998); OHIO REV. CODE ANN. $\$ \$ 4771.01$ to 99 (Banks-Baldwin 1998); OKLA. STAT. ANN. tit. 821, $\$ 61$ (West Supp. 1998); TEX. Bus. \& COM. CODE ANN. $\S 8871$ (West Supp. 1998): WASH. REV. CODE ANN. \$\$ 18.175.030 to .070 (West Supp. 1998).

57 See ALA. CODE $\$ \S 8-26-24$ to -41 (1998); FLA. STAT. ANN. $\$ 468.4561$ (West Supp. 1998); GA. CoDE ANN. $\S \S 43-4 A-2$ to -16 (West Supp. 1998); IND. CODE ANN. $§ 4-5.1$ (West Supp. 1998); KY. REV STAT. ANN. $\S \S 518.010$ to .080 (Banks-Baldwin 1998); Miss. CODE ANN. $\S \S 71-41-01$ to -99 (1998); S.C. CODE ANN. § 59-102 (Law. Co-op. 1998); TENN. CODE ANN. §§ 49-7-2111 to -2113 (1998).

58. See MINN. STAT. ANN. § 325E.33(3).

59 See Colo. REV STAT. ANN. $\S \S 23-16-102$ to -105 (West Supp. 1998); Fla. STAT. ANN. $\S 468.4562$ (West Supp. 1998); KAN. STAT. ANN. \& 44-1502 (1998); KY. REV. STAT. ANN. $\S \S 518.010-518.080$ (Banks-Baldwin 1998); MISS. CODE ANN. $\S \S 71-41-01$ to -99 (1998); NEV REV. STAT. ANN. §§ 398.015-398.065 (Michle 1998); N.D. CENT. CODE §§ 9-15-01 to -02 (1998); TENN. CODE ANN. $\S \S 49-7-2111$ to -2113 (1998); TEXAS BuS. \& COM. CODE ANN. $\$ 8871$ (West Supp. 1998).

60. See COlo. ReV STAT. ANN. \$§ 23-16-102 to -105 (West Supp. 1998); Fla. STAT. ANN. $\S 468.4562$ (West Supp. 1998); Kan. STAT. ANN. $\$ 44-1502$ (1998); KY. ReV. STAT. ANN. $\S \S 518.010-518.080$ (Banks-Baldwin 1998); TENN. CODE ANN. § 49-7-2113 (1998).

61. S.C. CODE ANN. \$§ 59-102-30(A), (F) (Law. Co-op. 1998); TENN. CODE ANN. § 49-7-2113; 1998 Ala. Acts 98-132 (H.B. 197); 1998 Ky. Acts ch. 259 (H.B. 703).

62. See Bascuas, supra note 4, at 1609-14.

63. S. 6719, 221 st Leg. (N.Y 1997); S. 1237, 222d Leg. (N.Y 1999). 
the state. ${ }^{64}$ The conclusion is inescapable that these statutes are designed to regulate or punish any contact or influence that individuals not associated with a college or university may have with an athlete. This ban is clearly designed to allow the institution to control the revenues that its program generates. ${ }^{65}$

The reach of the most aggressive statutes is quite broad, especially those statutes that include prospective students withın the definition of "student-athlete." For example, if a high school senior living in Chicago signs a letter of intent to play football at Florida State, a resident of Chicago who talks to that senior about professional representation must register with the state of Florida before talking with the high school student or face civil and crimınal penalties in Florida. If a sophomore football player at the University of Maryland who lives in Los Angeles, Californıa is home for spring break and contacts a Los Angeles agent to talk about his market value, the California agent cannot talk to the player by phone or in the player's home without first registering in Maryland. If a woman who is a junıor plays basketball for the University of Texas and is from Milwaukee, Wisconsin, an agent from Milwaukee cannot talk to the girl's father in Milwaukee without violatıng the Texas statute. In each of these examples, the agent is subject to a state's sports legislation even though the agent does not and will not have any direct contact with the state.

The National Conference of Commissioners on Uniform State Laws (NCCUSL) has a draft "Uniform Athlete Agents Act" before it for consideration. ${ }^{66}$ The Model Act, which follows the modern trend, adopts the jurisdictional reach and substantive provisions of the broadest current statutes. The general provisions contained within the Act's Article One define an "agent" as anyone who contracts with a studentathlete or solicits, contacts, or recruits a student-athlete to sign a representation contract. $^{67}$ An "educational institution" is described as a "public or private junior high school, high school, junior college, college, or university that the student-athlete attends, last attended, or to which the student-athlete has expressed written intention to attend." ${ }^{.68}$ Finally, a "student-athlete means an individual who engages in, is eligible to engage in, or may be eligible presently, or in the future, to engage in any intercollegiate sporting event, contest, exhibitıon, or program."69 The Act expands its reach by including a contact ban on any student-athlete who expresses a written intent to attend an in-state institution. ${ }^{70}$ The registration requirements in the Act's Artıcle Two prevent an agent from contactıng or contractıng with any student-athlete prior to registration with the state and notification of the athletic director at the educational institution. ${ }^{71}$ If the student-athlete or someone on his or her behalf initiates the contact with the agent, the agent must file an application for registration and notify the athletic director withın seven days of the contact. ${ }^{72}$ The Model Act

64. S. 6719, 221st Leg. (N.Y 1997).

65. See Bascuas, supra note 4, at 1629-30; Fluhr, supra note 8, at 22.

66. See UNIF. ATHLETE AGENTS ACT (Proposed Official Draft Sept. 1998). For a description of the procedures that govern the NCCUSL's creation of uniform laws, see Fluhr, supra note 8, at 9-12.

67 See id. \& 102(1).

68. Id. $\S 102(5)$.

69. Id. § $102(11)$.

70. See id. \& 102(5).

71. See id. § 201(a).

72. See id. § 202(a). 
exempts an agent from many of the registration details if the agent proves to the state that he or she has registered previously in another state with similar requirements. ${ }^{73}$ If a student-athlete executes a contract with an agent, the contract must contain certain clauses described in Article Three of the Model Act, including a boldface notice regarding loss of collegiate eligibility and encouragement of the student-athlete to talk to his or her coach before signing. ${ }^{74}$ Within seventy-two hours of the execution of the contract, or prior to the student-athlete's next athletic event, whichever comes first, the agent and the student-athlete must notify the athletic director of the educational institution. ${ }^{75}$ The Model Act also contains a detailed registration process (including specified fees, an application form and proof of liability insurance in a minımum amount of $\$ 100,000$ ), a student-athlete's right to cancel a contract within seven days of execution, recordkeeping requirements and prescribed sanctions (including civil remedies for the educational institution, adminıstratıve penalties and crimınal punishment). ${ }^{76}$

The Model Act therefore embodies most of the principles of the "aggressive" sports legislation already in existence. The Model Act would sanction all of the examples previously discussed. By including junior high school students within its scope, the Model Act potentially criminalizes a conversation between an uncle and his eighth grade nephew, if the uncle states that he will represent the nephew if he ever plays in the NFL. Before having that conversation, the uncle would be required to notify the junior high school athletic director and register with the state. As also noted earlier, a local merchant can give the senior football star of the area high school a $\$ 40,000$ car to induce him to attend the state university The payment on behalf of the educational institution does not come within the proscription of the Model Act. Similarly, a coach for a summer Amateur Athletıc Unıon (AAU) basketball team can offer a high school basketball star financial inducements to play for his summer team and not be within the purview of the Model Act. Finally, if a football player at the University of Georgia returns home to Seattle, Washington, after the fall semester of his junior year with the intent of turning professional and not returning to Georgia, an agent based wholly in Seattle would be subject to Georgia law and would need to register with the state of Georgia and notify the Georgia athletic director before the Seattle agent could contact the player in his Seattle home. ${ }^{77}$

\section{VAlidity of STATE STATUTES}

The widespread passage of sports agent legislation by the states raises two significant issues concerning the statutes' validity' legislative jurısdiction and the dormant Commerce Clause. Princıples of legislatıve jurısdictıon limit the ability of a state's legislature to impose a rule of substantıve law, civil or crımınal, on an individual or entity not withın its borders or affecting the state. Legislative

73. See id. $\S 201(\mathrm{c})$.

74. See id. $\$ 301(\mathrm{c})$.

75. See $t d . \S 302(\mathrm{a})$.

76. See $\imath d$. $\S 201$. For a summary of the Model Act and anticıpated comments, see Fluhr, supra note 8 , at $12-21$.

77. For a summary of agent actions prohibited by Article Four of the Model Act, see Fluhr, supra note 8 , at $18-19$ 
jurisdiction therefore involves principles of territoriality and sovereignty which restrict the power of one state to bind the nation. ${ }^{78}$ The principles of the dormant Commerce Clause limit any state's ability to interfere with the national economy and the free flow of goods and services in interstate commerce. ${ }^{79}$ As such, the Constitution's grant of power to the federal government to control the national economy dictates that no state may favor in-state economic interests to the detriment of out-of-state business or excessively burden "traffic" in interstate commerce. ${ }^{80}$ Each of these doctrines poses significant questions regarding the validity of state regulation of sports agents.

\section{A. Legislative Jurtsdiction}

The law delineating the legislative power of the states is not very clear or wellestablished. After many years of doctrinal turbulence, the United States Supreme Court has at least clarified a primal concept establishıng the limits of legislatıve jurisdictional validity The test created by the Court is similar to that enunciated for choice of law decisions by the judicial system: the "State must have a significant contact or sıgnificant aggregation of contacts, creatıng state interests, such that choice of its law is neither arbitrary nor fundamentally unfair." also indicated that the appropriate definition of jurisdictional limitations should not change depending on the Constitutional provision selected as the source of the limitation. ${ }^{82}$

In general, states may not enact statutes that proscribe conduct outside their own borders. ${ }^{83}$ Asıde from this agreed upon statement of the general rule, courts and commentators have differed in their application of the Supreme Court concept mentioned above to states' efforts to expand their legislative reach. In the context of criminal law, some conduct or the result of some conduct must occur within a state for that state to prosecute a defendant. ${ }^{84}$ Under the older theory of subjective territoriality, the state in which the defendant is located at the tıme the crime was committed has jurisdiction to sanction the offense. ${ }^{85}$ The modern theory of objective territonality, however, extends the situs of the crime to include the state where injury occurred regardless of the defendant's location. ${ }^{86}$ The Supreme Court has treated this concept of objective territoriality as an exception to accepted jurısdictional notions and has therefore limited its application to acts that are intended to have, and actually

78. See WILliam M. RichMan \& WILliam L. REYNOLDS, UNDERSTANDING CONFLICT OF LAWS 269 (2d ed. 1993).

79. See Philadelphia v New Jersey, 437 U.S. 617, 623 (1978).

80. See infra notes $96-113$ and accompanying text.

81. Phillips Petroleum Co. v. Shutts, 472 U.S. 797, 818 (1985) (citıng Allstate Ins. Co. v. Hague, 449 U.S. 302, 312-13 (1981)).

82. See RICHMAN \& REYNOLDS, supra note 78, at 282 . The Supreme Court applies the same test in defining state junsdictional limits under etther the Due Process Clause or the Full Faith and Credit Clause. See $i d$.

83. See RestatEMENT (SECOND) OF CONfLICT Of LAWs $\S \S 1,3$ (1971). See generally Willis L.M. Reese, Legislative Jurisdiction, 78 CoLUM. L. REV. 1587 (1978).

84. See WAYNE R. LAFAVE \& AUSTIN W SCOTT, JR., CRIMINAL LAW 133 (2d ed. 1986).

85. See People v. Blume, 505 N.W.2d 843, 845 (Mich. 1993).

86. See id. at 854-55 (Boyle, J., dissentıng). 
do have, a detrimental effect within the state. ${ }^{87}$ Pursuant to this "intended effects" test, "any state may impose liabilities, even upon persons not withın its allegiance, for conduct outsıde its borders that has consequences withın [its] border which the state reprehends" but only if that conduct was intended to adversely affect the state and if it actually had such an effect. ${ }^{88}$ Therefore, an individual standing in North Carolina who shoots across the border and kills someone standing in Virginia can be made subject to Virgınıa's crımınal laws. Similarly, if an individual stabs someone in Michıgan and the victım drıves back into Ohıo while bleeding and dies in Ohıo, the stabber can be subjected to Ohıo's crimınal law. However, a person who shoots and kills someone in Arızona cannot be subjected to Californıa's crımınal law sımply because the victım was a Californıa citızen. ${ }^{89}$

The tests for limiting legislative jurisdiction in the context of civil regulatory statutes is differently phrased. Courts in this setting tend to parallel more closely the choice of law language employed in conflicts of law ${ }^{90}$ If legislative jurisdiction is questioned in a contracts settıng, the court will examıne the relationship between the state and the contract. If a contract is neither performed nor executed within the state, legislatıve jurısdiction is usually lackıng. ${ }^{91}$ If a state attempts to impose its antitrust statute on a defendant, the court will determine whether the defendant has the requisite minımum contacts with the state to justify the exercise of legislative jurisdiction. Such contacts can be few if those contacts, which actually exist, give rise to the application of the statute. ${ }^{92}$

The above example of the junior Georgia football player who returns home to turn professional and is contacted at his Seattle home by a Seattle-based agent provides a basis for assessing the validity of the agent regulatory statutes in both their criminal and civil application. In this hypothetical, the agent does not register with the state of Georgia or inform the Unıversity of Georgia of any dealings with the player. The agent contacts the player in Seattle, meets him numerous tımes in Seattle and, one month after the initial contact, signs the player to a representation agreement in Seattle. Three months later, the player is drafted in the first round by the New York Giants and the agent negotiates a player contract with the Giants. The Giants play their fourth game of the season in Atlanta and the agent flies to Atlanta to watch the game. In his hotel the Saturday before the game, he is arrested by Atlanta police for failure to comply with Georgia's version of the Model Act regarding his contactıng and signing the player.

87 See Strassheim v. Daily, 221 U.S. 280, 284-85 (1911); Deur v. Newaygo Sheriff, 362 N.W.2d 698, 702 (Mich. 1984).

88. United States v Aluminum Co. of America, 148 F.2d 416, 443 (2d Cir. 1945). See, e.g., Rivard v United States, 375 F.2d 882, 887 (5th Cir. 1967).

89. See generally Rivard, 375 F.2d at 882; People v Blume, 505 N.W.2d 843 (Mich. 1993); LAFAVE \& SCOTT, supra note 84 , at 135-36.

90. See Jonathan R. Macey \& Geoffrey Miller, The McCarran-Ferguson Act of 1945: Reconceiving the Federal Role in Insurance Regulation, 68 N.Y.U. L. REV 13, 33-37 (1993).

91. See id.

92. See Herbert Hovenkamp, State Antitrust in the Federal Scheme, 58 IND. L.J. 375, 381-82 (1982-83). 
Since the agent was arrested within the state of Georgia, the state court would have judicial jurisdiction over the agent based on physical presence within the state. ${ }^{93}$ In the ensuing trial, a preliminary question would be whether Georgia had legislatıve jurısdiction sufficient to justify making the Washington actıvitıes crimınal in Georgia. If the agent regulation statute were seen as crimınal, Georgia would not appear to have legislative jurisdiction over the agent. The player's loss or renunciation of hıs remaınıng collegiate eligibility would not satisfy the intended effects test applied in a crimınal context. As noted above, a mere deleterıous effect on a citizen or state entity is not enough to justify legislative jurisdiction. ${ }^{94}$ If the statute was perceived as a civil regulation and the contacts test was employed, the state would still lack legislative jurisdiction since the agent had no contact with Georgia. ${ }^{95}$ Therefore, the most far-reaching statutes, such as the Model Act, contain serious jurisdictional defects as applied to agents who have never entered the state. The states possess greater jurısdictional credibility regarding statutes which regulate agent activities which actually occur in the state. Therefore, if a representation contract was executed within the state, or the agent made a number of trips into the state to meet with the athlete, the test for civil legislatıve jurısdiction would appear to be satısfied. If an out-of-state agent, however, merely telephoned an athlete instate and then met the player at away games and trips to the agent's out of state office, state civil jurisdiction would still be serıusly questioned.

\section{B. Dormant Commerce Clause}

In the absence of federal legislation, the Constitution's mandate that the federal government shall regulate interstate commerce has been construed as limitıng the ability of the states to control economic matters. ${ }^{96}$ The Supreme Court has declared that this "dormant" Commerce Clause doctrine can be violated by a state in any one of three ways: (1) a state favoring the economic interests of its residents over those of out-of-state entities seeking to do business within the state (protectionism); (2) regulation by a state or states creating the impermissible risk of inconsistent regulation by different states of the same economic entity or creating a cumulative burden which stifles the economic activity; or (3) a state placing a burden on the free flow of goods and services in interstate commerce which outweighs the local benefits the state is attempting to advance. ${ }^{97}$

93. See People v. Blume, 505 N.W.2d 843, 855 (Mich. 1993) (Boyle, J., dissentıng). See also RICHMAN \& REYNOLDS, supra note 78, at 14-15 (explaining the histoncal roots of judicial jurisdiction based on the physical control of the defendant).

94. See LAFAVE \& SCOTT, supra note 84, at 135-36.

95. The student-athlete's attendance at a Georgia educational institution would not seem to be a sufficient contact to bind the agent. See Dunn, supra note 9, at 1065.

96. See Gibbons v. Ogden, 22 U.S. (9 Wheat.) 1 (1824).

97. See CTS Corp. v. Dynamics Corp. of America, 481 U.S. 69, 87-89 (1987). 


\section{Protectionism}

A state statute can exhibit traces of protectionism etther on its face, in its purpose, or in its effect. ${ }^{98}$ The sports agent legislation is clearly neutral on its face because all agents who contact or contract with defined athletes are subject to regulation, regardless of their residence. Therefore, in-state and out-of-state economic entities are treated similarly by the state. The purpose underlying these statutes is also neutral. A state desires to "protect" its athletes and NCAA institutions from all agents, in-state and out-of-state in origin. The effect of the statute does not impose burdens only upon out-of-state agents. Therefore, as currently drafted, the states' regulation of agents does not appear to violate the prohibition against protectionism.

\section{Impossibility or Cumulative Burden}

State statutes may also be invalidated under the dormant Commerce Clause because of the multıplicity of states who have or may enact differing statutes. In such a situation, compliance with all of the statutes needed to conduct an agent's national business may be impossible or, at the least, extremely difficult. ${ }^{99}$ Dormant Commerce Clause jurisprudence would invalidate the statutes on either the real or hypothetical impossibility of compliance with all statutes, or the impermissible burden placed on a national business by the sheer volume of statutory requirements. ${ }^{100}$

Many statutes require sports agents to submit a surety bond to the state treasurer in amounts ranging from $\$ 10,000$ to $\$ 100,000$ as one of the requirements for obtainıng a sports agent license. ${ }^{101}$ This financial burden, multiplied by the number of states with such a requirement, may make compliance with each statute impossible. The statutes currently in existence, however, do not expressly make illegal in one state an action that is expressly legal or specifically mandated in another. ${ }^{102}$ Therefore, compliance with all statutes, while difficult, 1s, in fact, possible. The existent array of regulatory legislation would not appear to violate the impossibility of compliance branch of the dormant Commerce Clause doctrine.

The multiplicity of regulations hamper an industry that is unquestionably national in scope. The differing state regulations place a cumulatıve burden on interstate commerce which is unacceptable under dormant Commerce Clause theory ${ }^{103}$ The broad applicability of the most aggressive legislation makes it impossible for an agent to know, prior to contactıng the athlete, what regulations may be applicable. In order to protect hımself or herself from civil and crimınal liability, an agent must comply

98. See Philadelphia v. New Jersey, 437 U.S. 617, 623-24 (1978).

99. See Bibb v. Navajo Freight Lines, Inc., 359 U.S. 520, 527-28 (1959); Southern Pacific Co. v. Ar1zona, 325 U.S. 761,767 781-82 (1945).

100. See CTS Corp., 481 U.S. at 88-89.

101. See CAL. BuS. \& Prof Code $\S \S 18896,18897.87$ (West Supp. 1998); Fla. Stat. ANN. $\S 468.453$ (West Supp. 1998); GA. CODE ANN. \& 43-4A-4 (West Supp. 1998).

102. See Brown-Forman Distillers v. N.Y. Liquor Auth., 476 U.S. 573, 583-84 (1985).

103. See Cooley v. Board of Wardens, 53 U.S. (12 How.) 299 (1851). See also Dunn, supra note 9, at 1066 . 
with the regulation of every state, no matter how costly, on the off chance that a prospective client might have some distant tie to that state. This reality means, in effect, that the most restrictive legislation must be followed in order to avoid a violation. The sheer volume of compliance makes it difficult or impossible to maintain a national business. The dormant Commerce Clause prohibits such a result. In addition, such a "mandated" national compliance with the statutes of the most restrictive states violates the dormant Commerce Clause because those states are given authority well beyond their borders and are, in effect, exercising the power to regulate the national economy ${ }^{104}$ Such control as stated in the Constitution is exclusively federal and, therefore, beyond the authority of any state or states.

\section{Balancing}

In addition to examining the burden multiple regulations impose on an industry, a related, but separate, dormant Commerce Clause analysis compares the burden on interstate commerce with the importance of local benefits derived from the state legislation. ${ }^{105}$ The Supreme Court has enunciated several descriptions of the appropriate weighing and balancing of interests required by the Constitution. If the state statute advances an "important" state purpose, the burden on interstate commerce should probably be declared incidental unless a "special" need exists for national uniformity within the industry ${ }^{106}$ A slightly different formulation of the balancing test states that the legislation will be upheld unless the burden on interstate commerce is excessive in relation to putative local benefits. ${ }^{107} \mathrm{~A}$ court should also take into account the nature of the local interest and whether it can be promoted by other means which will have less impact on interstate activities. ${ }^{108}$

As noted previously, most states assert four justifications for these statutes. ${ }^{109}$ The state's concern for the athlete's education is tempered by the low graduation rates in most Division I football and basketball programs and a subordination of academic concerns to athletic interests while the athlete is actually attending the college or university ${ }^{110}$ Concern for the disqualification of the student and the institution should dictate that coaches and alumnı or boosters who violate NCAA rules should also come within the purview of the act. ${ }^{11}$ Any negative publicity directed towards professional sports is clearly temporary and not of any real concern to the state. The actual purpose of these statutes is to protect the competitiveness and profitability of

104. See Forman Distillers, 476 U.S. at 584-85; Bibb, 359 U.S. at 520-21.

105. Some Justices believe that balancing is not an appropriate function of the Supreme Court and therefore should not be a consideration in the dormant Commerce Clause analysis. See Bendix Autolite Corp. v. Midwesco Enters., Inc., 486 U.S. 888, 897 (1988) (Scalia, J., concurnng). This balancing may, in practical effect, be the same as assessing the burden placed on a national industry referenced in the prior section.

106. See Kassel v. Consol. Freightways Corp. of Delaware, 450 U.S. 662, 675 (1981).

107 See Pike v. Bruce Church, Inc., 397 U.S. 137, 142 (1970).

108. See id.

109. See supra notes 61-62 and accompanying text.

110. See supra note 17 and accompanying text. See also Bascuas, supra note 4, at 1608 (statıng that Division I athletes are required to complete only $25 \%$ of their degree requirements after two years, $50 \%$ after three years, and $75 \%$ after four years of enrollment).

111. See supra note 7 and accompanying text. 
in-state teams in the big revenue sports of men's football and basketball. ${ }^{112}$ Although probably critical to in-state fans and the local electorate, these purposes would not appear to be terribly important in the mandated balancing required by the Constitution. The burden of complying with these various state statutes significantly hampers an entire industry, which is clearly national in scope. ${ }^{113}$ The state purposes motivating the statute are trivial and provincial. In the balancing required by the Supreme Court, the burden on interstate commerce would, therefore, appear to outweigh any state's interest in keeping its collegiate athletes playing for the local school and avoiding NCAA sanctions.

\section{NATIONAL REGULATION}

To date, the federal government has not passed national legislation dealing with the sports agent industry Congress, however, has recently considered two such proposals. ${ }^{14}$ In addition, the unions of all the major professional sports now regulate the conduct of certıfied agents in their sports. These union regulations proscribe many activities by sports agents as unethical, including many practices that are regulated by the state statutes. ${ }^{115}$

\section{A. Congress}

In 1996, Congress consıdered an amendment to Title 18 of the U.S. Code that would have prohibited sports agents from "influencıng" college athletes to term inate their eligibility to partıcıpate in intercollegıate athletıcs. ${ }^{116}$ Rather than requirıng registration and licensing for athlete agents, the bill, through its definition of the term "influence," essentially criminalized any contact between an agent and a college athlete. ${ }^{17}$ The bill defined "athlete agent" as anyone who solicits a college athlete to enter into a contract authorizing such person to represent the athlete in marketıng his or her athletic ability "College athlete" was defined as anyone enrolled in an undergraduate or graduate degree grantıng program who etther partıcıpates in or has informed the school in writing of an intent to participate in intercollegiate athletics. ${ }^{119}$ This bill would have provided a single national rule for agents, but it would not have significantly clarified the field. The concept of "influencing" is vague unless it is enforced to the extreme of banning all contact between the agent and athlete. The bill also did not clearly pre-empt the registration and licensing requirements of the states. ${ }^{120}$ Fortunately, this bill died in the 1997 Judiciary Committee. ${ }^{121}$

112. See Stiglitz, supra note 2 , at 216-17.

113. See Dunn, supra note 9, at 1066; Fluhr, supra note 8, at 23-24.

114. See H.R. 3328, 104th Cong. (1996); H.R. 2171, 105th Cong. (1997). See also infra notes 115-127 and accompanying text.

115. See infra notes 132-135 and accompanying text.

116. See H.R. 3328, 104th Cong. \$ 226 (1996).

117 See id.

118. See $\imath$ d. $\$ 226(\mathrm{~b})(2)$.

119 See id. $\$ 226(\mathrm{~b})(3)$.

120. In order to provide the full benefits of national regulation, a federal statute should completely and explicitly pre-empt all state law on the subject. See Pacific Gas \& Elec. Co. v. State Energy 
A second attempt to enact a national sports agent statute was made in Congress in 1997 Rather than sanctioning agents for influencing student-athletes, this bill provides for the extensive regulation seen in most of the current state statutes. ${ }^{122}$ First, the bill prohibits contact between an agent and any student-athlete currently subject to the rules and regulations of the NCAA or the NJCAA. ${ }^{123}$ Upon the first violation of the statute, an agent would be prohibited from representing any studentathlete who attends the college or university at which the offense occurred. ${ }^{124}$ Any subsequent violation would subject the agent to conviction of a Class $\mathrm{C}$ felony and a fine. ${ }^{125}$ The statute also regulates the contractual language in representation agreements between student-athletes and agents, specifically requiring notıfication in bold type that contracting with an agent will terminate the student-athlete $s$ eligibility to partıcipate in intercollegiate athletıcs. ${ }^{126}$ The educational institution must be notified of the agreement within seventy-two hours of its creation and the athlete is granted a twenty-day recision period. ${ }^{127}$ Most importantly for notice purposes, the statute limits the definition of student-athlete to "any athlete who practices for or otherwise participates in intercollegiate athletics at any college or university "128 This bill was referred to the Committee on Education and the Workforce on July 16, 1997 and is still pending. ${ }^{129}$

A Congressional statute regulating sports agents would clearly be withın Congress' power pursuant to the Commerce Clause. ${ }^{130}$ The passage of a national regulation would seem to benefit all the parties concerned with intercollegiate athletics. The schools would receive protection for their financial and athletic interests. The agents would only have one registration and one set of regulations with which to comply The serious questions regarding the validity of state statutes in connection with legislatıve jurisdiction and the dormant Commerce Clause would be elimınated. The inconsistencies in current state law could be eliminated by encompassing within a federal statute the activities of coaches, alumnı, and boosters. Even federal legislation, however, does not seriously examıne whether this type of statute is fair to the student-athlete. Although such a national statute would eliminate the technical, legal objections to state regulation of sports agents, the larger question of whether any legislation giving NCAA rules the force of law is a proper function of government would remain unasked and unanswered. ${ }^{131}$ The majority of Congress may in fact be implicitly indicating their opınıon by their failure to take any meaningful action on the pending legislation. To date, no federal statute appears close to passage.

Resources Conservation \& Dev. Comm'n, 461 U.S. 190, 206 (1983).

121. See H.R. 3328, 104th Cong. (1996).

122. See H.R. 2171, 105th Cong. \& 2 (1997).

123. See Id. § 2(a). The NJCAA is the National Junior College Athletic Association.

124. See $1 d$ \& 2(b)(1).

125. See id. $\S 2(\mathrm{~b})(2)$.

126. See id. \$3(5).

127 See id. \$ 4.

128. Id. $\S 4(3)$.

129. See H.R. 2171, 105th Cong. (1997) (pending).

130. See generally Wickard v Filburn, 317 U.S. 111 (1942); Unted States v Darby, 312 U.S. 100 (1941); NLRB v. Jones \& Laughlin Steel Corp., 301 U.S. 1 (1937).

131. See Bascuas, supra note 4, at 1617-18 (arguing that even federal legislation is inappropriate). 


\section{B. Professional Sports Unıons}

The unions in each of the major professional team sports have the power to regulate the registration and conduct of sports agents pursuant to their role in collective bargainıng. ${ }^{132}$ These labor groups have all exercised this power, providing for a full application and review process for becoming an agent, and a detailed code of conduct that delineates particular activities as unethical and indicates the appropriate sanction for proven violation. ${ }^{133}$ These codes of conduct generally proscribe providing money or any other financial benefit to induce an athlete to sign with an agent. ${ }^{134}$ These regulations control, in substantial effect, the same agent conduct made criminal by the state statutes without a reference to NCAA rules. Current union codes, however, only provide union-imposed remedies for aggnieved athletes or agents and sanctions, usually a fine or suspension, for unethical agents. ${ }^{135}$ These regulations do not provide a mechanism for the colleges to reclaim lost revenue from the agents.

\section{CONCLUSION}

Current state statutes that regulate sports agents are of questionable validity because of concerns regarding legislatıve jurısdiction and the dormant Commerce Clause. If state regulation is to continue, statutes should clearly be limited to agents and athletes residing within the state or having contacts with the state. Federal legislation, which completely preempts state law, would be preferable to state regulation. National regulation would simplify the registration process and provide notice to agents of the one set of rules with which they must comply. Any legislation, including federal, regulating sports agents should be seriously questioned. No government should give the force of law to a portion of the rules of a private athletic association to benefit its collegiate sports fans. By crimınalizing the NCAA rules, the state penal code is forced to adopt the hypocrisy and duality of Division I athletics. These statutes are on the books, but rarely enforced. They are ignored in the same manner that NCAA rules on amateurism are ignored. The net effect is that ethical agents will not recruit athletes in a state where they are not registered or will be burdened with multiple compliance just to talk to a student-athlete. Unscrupulous agents will simply ignore the requirements and contınue to contact and sign players.

132. See Collins v NLRB, 850 F Supp. 1468,1475 (D. Colo. 1991).

133. The National Football League Players Association (NFLPA), the National Basketball Players Association (NBPA), the Major League Baseball Players Association (MLBPA), and the National Hockey League Players Association (NHLPA) all have regulations providing for the certification and regulation of agents in their sport. See Fluhr, supra note 8, at 7-8. Collective bargaining provisions in all of the sports also provide that member clubs will only deal with certified agents. See, e.g., NFL Collectıve Bargaınıng Agreement 1993-2000, art. VI, § I (stating teams will exclusıvely negotıate with union-certified agents).

134. See, e.g., NFLPA CODE OF CONDUCT FOR NFLPA MEMBER CONTRACT ADVISORS § 3(b) (1994).

135. See $\imath$. $\S \S 5-6$. 
The activities of college coaches and school boosters, which equally threaten loss of eligibility and revenue, will contınue with no fear of legal sanction.

Athletics are best left to private, not public, regulation. The codes of conduct of professional sports unions are an example of private sector activity that can control at least the most flagrant abuses performed by sports agents. The NCAA should critically evaluate its existing rules and honestly discuss whether they make sense in the modern economic realities of Division I football and basketball. Governmental regulation of sports agents is inhibiting the effectıve workıng of the marketplace in athletics and delayıng an effective resolution of deeper issues regarding amateurism and the proper role of educational institutions in a multi-billion dollar athletic and entertainment industry 